\title{
The Analysis of PPKn Teacher Pedagogic Competency in Learning Activities at state high school 9 Sinjai, Tellulimpoe District
}

\author{
Jumiati Nur ${ }^{1)}$, Arahim ${ }^{2)}$, Hasrianto ${ }^{3)}$ \\ Pancasila Education and Citizenship Study Program Faculty of Teacher Training and Education \\ Universitas Muhammadiyah Makassar, Indonesia 1,2,3) \\ jumiatinur@unismuh.ac.id ${ }^{1)}$, arahim@unismuh.ac.id ${ }^{2)}$, hasrianto@unismuh.ac.id ${ }^{3)}$
}

\begin{abstract}
Pedagogic competence is the ability to manage student learning. The teacher must own competence because it is related to the characteristics of students seen from various aspects such as physical, moral, social, cultural, and intellectual. This implies that a teacher must master learning theories and educational learning principles because students have different characters, traits, and interests. This type of research uses qualitative research where this research is expected to explain the existing phenomena, especially those related to the pedagogic competence of Pancasila and Citizenship Education teachers. This study indicates that the pedagogical competence of PPKn teachers in SMA Negeri 9 Sinjai Kec. Tellulimpoe has a fairly good ability in mastering the characteristics of students, applying the principles of curriculum development related to the subjects being taught, mastery of learning theory using one method but using several learning methods, teachers have used technology, information, and communication in the interests of learning.
\end{abstract}

Keywords: Pedagogic Competence, Teacher, School.

\begin{abstract}
Abstrak. Kompetensi pedagogik adalah kemampuan mengelolah pembelajaran peserta didik. kompetensi harus dimiliki guru karen berkenaan dengan karakteristik peserta didik dilihat dari berbagai aspek seperti fisik, moral, sosial, kultural, dan intelektual. Hal tersebut berimplikasi bahwa seorang guru harus mampu menguasai teori belajar dan prinsip-prinsip pembelajaranyang mendidik karena peserta didik memiliki karakter, sifat, dan interes yang berbeda. Jenis penelitian ini menggunakan kualitatif dimana penelitian ini diharapkan dapat menjelaskan fenomena yang ada terutama yang berkaitan dengan kompetensi pedagogik guru Pendidikan Pancasila dan Kewarganegaraan. Hasil penelitian ini menunjukan bahwa kompetensi pedagogik guru PPKn di SMA Negeri 9 Sinjai Kec. Tellulimpoe telah memiliki kemampuan yang cukup baik dalam menguasai karakteristik peserta didik, menerapkan prinsip-prinsip pengembangan kurikulum yang berkaitan dengan mata pelajaran yang di ampu, penguasaan teori belajar tidak hanya menggunakan satu metode saja tetapi menggunakan beberapa metode belajar, guru telah memanfaatkan teknologi, informasi dan komunikasi dalam kepentingan pembelajaran.
\end{abstract}

Kata Kunci: Kompetensi Pedagogik, Guru, Sekolah. 


\section{INTRODUCTION}

Education in terminology can be interpreted as coaching, formation, direction, intelligence, and training aimed at all students formally to form intelligent personalities and have specific skills or expertise as provisions in life in society. Formally, education is teaching (at-tarbiyah, at-ta'lim). From this understanding, in general, education is the process of developing human beings physically and spiritually. Every effort and effort to improve students' intelligence is related to increasing intelligence, emotion, and intelligence to have spirituality. Students produce skills and have professional skills or expertise for provision in the community. On the other hand, the maximum search must be as much as possible to benefit society, especially for oneself and their families, and achieve their life goals in this world and hereafter.

Education is an effort that educates, guides, fosters, influences, and directs every student, which can be done formally. Educational institutions, schools, families, and the community, and the surrounding environment can be a medium for education or the dissemination of knowledge.

The purpose of education is the desired change, which is sought by the educational process or educational effort to achieve it, both in individual behavior and in personal life or community life and the natural surroundings.
The main element in educational institutions is the teacher as a teacher who is expected to have competence following his teaching field. This will facilitate the transfer of knowledge to students. Competence is the capacity to do something that is produced in the teaching and learning process. During the learning process, the stimulus will join the memory contents and cause a change in the capacity to do something. If a successful individual learns how to do a complex job from before, then the individual must have experienced a change in competence.

Competence is a unified whole that describes the assessed potential, knowledge, skills, and attitudes related to a particular profession concerning the parts that can be actualized and realized in the form of action or performance to carry out a particular profession.

Pedagogic competence is the ability to manage student learning. Other competencies are personality competencies, which are strong personal abilities, have a noble character, are wise and authoritative, and become role models for students. This ability is in the form of the ability to design learning in line with high school subjects. Furthermore, teachers are also required to take real action in the classroom in providing information in an empathic, polite, and effective manner.

After carrying out educational learning, teachers are also required to evaluate all learning activities carried out through in-depth 
evaluation actions and reflective steps based on further research as objective criticism for future teachers. As stated in the Appendix to the Regulation of the Minister of National Education Number 16 of 2007 concerning Standards of Academic Qualification and Teacher Competence, teachers must take reflective actions to improve the quality of learning. At this stage, the teacher takes steps to reflect or remember and re-evaluate learning activities on the material that has been given.

According to (Law No. 14 of 2005; Minister of National Education Regulations (Permendiknas) No. 16 of 2007) concerning standards for academic qualifications and teacher potential, pedagogic competencies include:

1. Understanding the characteristics of students from the physical, moral, spiritual, social, cultural, emotional, and intellectual aspects.

2. Mastering learning theory and educational learning principles.

3. Develop a curriculum related to the subjects taught.

4. Organizing educational learning.

5. Utilizing information and communication technology for learning.

6. Facilitate the development of the potential of students to actualize their various potentials.

7. Communicate effectively, empathically, and politely with students.
8. Conducting assessment and evaluation of learning outcomes process.

9. Utilize the results of the assessment and evaluation for the benefit of learning.

10.Take reflective action to improve the quality of learning.

However, the pedagogic competence of teachers to this day is still a discussion in terms of understanding the character of students, implementing learning, utilizing assessment results, and reflective actions that need to be taken by teachers in terms of improving the quality of learning or not.

Teachers are the most influential component in the creation of quality educational processes and outcomes. Therefore, any improvement efforts made to improve the quality of education will not make a significant contribution without professional and qualified teachers and have good pedagogic competence capabilities.

The phenomenon that often occurs in teacher behavior is that the teacher assumes that all the students he fosters have the same characteristics in the learning process. The teacher generalizes the level of intelligence, creativity, and cognitive development so that the teacher does not understand the strengths and weaknesses of the students. Lack of teacher creativity in determining various approaches, strategies, methods, and techniques in learning. Development of the potential of students. In providing enrichment 
to students, it is only done once, and there is no feedback from a teacher.

The future goal to be achieved through this research is to see the pedagogic competence of State high school 9 Sinjai teachers as teachers in understanding learning management, with the Regulation of the Minister of National Education Number 16 of 2007 concerning Academic Qualification Standards and Teacher Competencies.

\section{RESEARCH METHODS}

This type of research was qualitative research, where this research was expected to explain the existing phenomena, especially those related to the academic competence of Pancasila and Citizenship Education teachers. To obtain feedback from activities that were used to improve/improve the teacher's competence to be studied. Qualitative research aims to describe and analyze phenomena, events, social activities, attitudes, beliefs, perceptions, and thoughts of people individually and in groups.

The approach used in this research is to use descriptive qualitative, which is one type of research included in the type of qualitative research. This research aims to reveal events or facts, circumstances, phenomena, variables, and circumstances that occurred during the research by presenting what happened. This study interprets and describes the data concerned with the current situation, attitudes, and views in a learning process, the conflict between two or more circumstances, the relationship between variables that arise, the differences between existing facts, and their influence on a condition, etc.

The approach used in this research is to use descriptive qualitative, which is one type of research included in the type of qualitative research. This research aims to reveal events or facts, circumstances, phenomena, variables, and circumstances that occurred during the research by presenting what happened. This study interprets and describes the data concerned with the current situation, attitudes, and views in a learning process, the conflict between two or more circumstances, the relationship between variables that arise, the differences between existing facts, and their influence on a condition, etc.

The approach used in this research was to use descriptive qualitative, which was one type of research included in qualitative research. This research aimed to reveal events or facts, circumstances, phenomena, variables, and circumstances that occurred during the research by presenting what happened. This study interpreted and described the data concerned with the current situation, attitudes, and views in a learning process, the conflict between two or more circumstances, the relationship between variables that arise, the differences between existing facts, and their influence on a condition, etc.

The research subject was the source of the data we examined using the method we had 
previously determined, and the method ought to be under what we were researching. These research points are Pancasila and Citizenship Education teachers at State high school 9,Sinjai Regency.

Data collection techniques using Interviews are one effective way to obtain information by asking directly to Pancasila and Citizenship Education teachers. Without interviews, researchers had difficulty obtaining information if data was obtained by asking directly, and (2) This documentation is intended to obtain research evidence in strengthening arguments and research results in the form of student and teacher data.

Data collection techniques using Interviews are one effective way to obtain information by asking directly to Pancasila and Citizenship Education teachers. Without interviews, researchers had difficulty obtaining information if data was obtained by asking directly, and (2) This documentation is intended to obtain research evidence in strengthening arguments and research results in the form of student and teacher data.

\section{DISCUSSION}

\section{Learning Preparation}

The preparation of learning in this research includes the making of lesson plans and learning theory. Teachers in making lesson plans and developing learning theories are adapted to students' learning experiences in the subjects of Pencasila and Citizenship
Education. The teacher adjusts the material being taught to the level of understanding of the students. Following are the results of the analysis of the lesson plans from several teachers who carried out the development of the syllabus according to the following points: 1. Learning objectives were formulated and developed based on the $\mathrm{KI} / \mathrm{KD}$ to be achieved.

2. Learning objectives contain a description of the learning process and outcomes that students can achieve in accordance with their learning needs.

3. Learning objectives are adjusted to the learning needs of students.

The approach made in the lesson plans is in accordance with the approach used in the 2013 curriculum, namely the scientific approach, and learning theory is the methods used to understand the behavior of individuals who are relatively sedentary as a result of experience and interaction with the environment. the function of the lesson plan is to find out learning. The success or failure of learning, so that learning is more coherent, for restrictions so that learning does not spread, and provides scope for students to be more active. The function of the lesson plan is as a reference for teachers to carry out teaching and learning activities (learning activities) so that they are more focused and run effectively and efficiently. In other words, lesson plans act as scenarios for the learning process. Therefore, lesson plans should be flexible (flexible) and 
allow teachers to adapt to students' responses in the actual learning process.

In preparing indicators, the teacher adjusts to the Competency Standards and Basic Competencies to be achieved. Learning objectives are developed based on the basic competencies to be achieved. The material used is from the student handbook, LKS (Student Worksheet), supporting books, and Electronic School Books. The methods and strategies used by the teacher in learning are adjusted to the material to be delivered. Teachers use different methods according to the interests or enthusiasm of students and prioritize that students participate actively during learning. In the learning step, all teachers have implemented the exploration, elaboration, and confirmation steps. In assessment, the teacher uses written and oral evaluation.

\section{Teaching and learning process}

Mastering and developing several communication strategies and techniques will automatically improve your ability to relate to a wide variety of people. An educator can create and develop effective communication through learning materials that are acceptable and easily understood by students. Mastering and developing several communication strategies and techniques will automatically improve your ability to relate to a wide variety of people. An educator can create and develop effective communication through learning materials that are acceptable and easily understood by students.

To equate the meaning between teachers/educators and students, several things need attention: (a) all components in learning communication are cultivated in ideal/good conditions: messages must be clear, in accordance with the curriculum, clearly structured, interesting and appropriate to the level the intelligence of students, (b) the encoding and decoding processes do not experience meaning/meaning refraction. (c) analogies must be made to help generate new understanding with the old understanding that they have received, (d) minimize the level of interference (barrier/noise) in the communication process starting from the source encoding process (semantical), the symbolizing process in software and hardware (mechanical). and the receiver's interpretation process (psychological), (e) the intensity of feedback and response must be increased to measure the effectiveness and efficiency of achievement, (f). Repetition must be carried out continuously or progressively, (g). Evaluation of processes and results must be carried out to see deficiencies and improvements, (h). 4 aspects of communication support; Physical, psychological, social, and time must be formed and harmonized with the ongoing communication conditions so as not to hinder the learning communication process. 
The application of an effective strategy in learning has several main components, the form of implementing an effective communication strategy in the learning process should pay attention to the main components, the elements referred to are 1) systematic communication, 2) communication methods for learning, 3) communication media, 4) time management. The ability/skills of the teacher in carrying out communication activities will affect the process that ultimately produces results. This is not mean that students are intelligent, which is caused by the ability of the teacher to communicate. Less intelligent students can examine messages/ideas transferred in a good communication process by a teacher skill.

Then in terms of media technology and information, teachers need to keep up with the times. Given that we are now living in the 3rd millennium era, of course, the use of technology can no longer be avoided, including in the world of education, technology is a tool that is often used to make learning media other than From a practical point of view, the use of technology in learning is also included in the demands of the world of education, the use of technology is also a special attraction for students because students tend to be more enthusiastic in learning. Media is a way of channeling the mandate between teachers and students. The mandate here means subject matter. There is a message that students must understand; therefore, the selection of learning media is very important so that the message conveyed by the teacher to students can be conveyed maximally, and students can understand the message given by the teacher.

Teachers in utilizing a media to be used in the teaching and learning process must pay attention to several things, namely (1) the learning objectives to be achieved, (2) the content of the subject matter, (3) the teaching and learning strategies used, (4) the characteristics of students who learn. The characteristics of the students who study in question are the level of knowledge of students about the media used, the language of students, meaning that the content of messages conveyed through the media must be adjusted to the level of language skills or vocabulary possessed by students so as to make it easier for students to understand the content of the material presented. Through the media. In addition, it is also essential to pay attention to the number of students. This means that the media used should be adjusted to the number of students studying.

\section{Evaluating Ability}

Evaluation of learning outcomes. Based on the research data findings, each teacher carries out periodic evaluations to see the achievement of competence. Teachers assess oral and written questions in the form of practice questions to students. The interview results found that teachers had difficulty with 
the assessment process in the 2013 curriculum, which consisted of three assessed aspects. Aspects assessed in the 2013 curriculum are knowledge, skills, and attitudes. These three aspects are then described as indicators of learning outcomes. The 2013 curriculum uses an authentic assessment model, but the teacher has not carried out the assessment. The teacher has only carried out observational assessments, written assessments, oral assessments, and practical assessments.

We must know several objectives in the evaluation of learning, including 1) To find out the learning progress of students after participating in learning activities within a certain period of time. 2). To determine the effectiveness of the learning method. 3) To find out the position of students in the group. 4). To obtain input or feedback for teachers and students to improve.

In the implementation of classroombased assessment, the teacher's role is very important in determining the accuracy of the assessment type to assess students' success or failure. The type of assessment made by the teacher must meet the standards of validity and reliability so that the results achieved are in accordance with what is expected. For this reason, pedagogic competence for teachers is an essential requirement. Class-based assessments carried out by teachers must provide significant meaning for parents and society in general, and individual students in particular, so that the development of student achievement from time to time can be observed (observable) and measurable (measurable). As part of the competencybased curriculum, the implementation of classroom-based assessment is strongly influenced by various factors and components. However, the teacher has a central position in determining the success and failure of assessment activities. For this reason, the implementation of the assessment must pay attention to the principles of being valid, educating, competency-oriented, fair and objective, open, sustainable, comprehensive, meaningful.

\section{CONCLUSION}

Based on the research results that the author did about "Analysis of Pedagogic Competence of Civics Teachers in Learning Activities at State High School 9 Sinjai Tellulimpoe residence ", the authors can conclude.

1. The competence of teachers in designing learning tools is very good. This can be seen from the seriousness of the teachers to prepare learning tools long before the start of the teaching and learning process. Teachers have been able to design learning tools that suit their needs. This cannot be separated from the government's intervention and the ministry of education in providing guidance and training to teachers. 
2. In the teaching and learning process, the teacher is quite good. The teacher's understanding of using technology media in designing learning devices and in the teaching and learning process is quite good. Then the obstacle is students' different characters, which causes teachers to have difficulty designing learning tools and in the teaching and learning process.

3. In evaluating teaching and learning, the teacher is good enough. In this case, the teacher provides an assessment and evaluation to students at the end of the lesson. With the evaluation results, the teacher can find out students who do not understand the learning that has been carried out.

\section{REFERENCES}

[1] Ahmadi Rulam, (2016) Pengantar Pendidikan, Yogyakarta AR-RUZZ MEDIA,

[2] Angga Putra Kurniawan, Pengaruh Kompetensi Pedagogik Guru Terhadap Motivasi Belajar Siswa Di Smp Negeri 5 Blitar,(skripsi, fakultas psikologi UIN Mulana Ibrahim malang, tidak dipublikasikan)

[3] Arifin. (2011) Kompetensi Guru dan Strategi Pengembangannya. Jakarta: Lilin Persada Press

[4] Asrul, Rusidy Ananda, Dkk, (2014). Evaluasi Pembelajaran. Bandung: CitaPustaka Media

[5] Budiningsih, Asri. (2005). Belajar dan Pembelajaran.Jakarta : Rineka Cipta.

[6] Moh. Uzer Usman. (1995). Menjadi Guru Profesional. Bandung: Remaja Rosdakarya.
[7] Depdikbud. (1986a). Kurikulum: Pedoman Proses Belajar Mengajar. Jakarta: Depdikbud.

[8] Evanita, E.L. (2013). Analisis Kompetensi Pedagogik Dan Kesiapan Guru SMA Dalam Mendukung Implementasi Kurikulum 2013.Skripsi. Semarang: FMIPA Universitas Negeri Semarang.

[9] Haling Abdul, (2007) Belajar Dan Pembelajaran, Makassar: Universitas Negeri Makassar

[10] Hambali, (2017) Profesi Pendidikan Fakultas Keguruan Dal Ilmu Pendidikan Universitas Muhammadiyah Makassar

[11] Hasnah, K., Amin, B., Syakur, A., \& Suardi, S. (2018). Peningkatan Hasilbelajar Bahasa Indonesia Melalui Model Pembelajaran Kooperatif Tipe Numbered Heads Together. JRPD (Jurnal Riset Pendidikan Dasar), 1(1), 25-33.

[11] Irma Ariyanti Arif, Analisis Kompetensi Guru Di Smk Negeri 1 Watampone, Kabupaten Bone,(skripsi Universitas Hasanuddin Fakultas Ilmu Sosial Dan Ilmu Politik Jurusan Ilmu Administrasi Program Studi Admi

[12] Miarso Y. (2008). Peningkatan Kualifikasi Guru dalam Perspektif Teknologi Pendidikan. Jurnal Pendidikan Penabur 7 (10):66-76.

[13] Munir Abdul, (2012) Pengantar Pendidikan Fakultas Keguruan Dan Ilmu Pendidikan Universitas Muhammadiyah Makassar

[14] Mustofa. (2007). Upaya pengembangan profesionalisme guru di Indonesia. Jurnal Ekonomi dan Pendidikan 4 (1):76-88.

[15] Nurdiansyah, Beni. (2016). Pedagogik. https://id.wikipedia.org/wiki/pedagogiby (diakses tanggal 22 Februari 2020)

[16] Karsidi R. (2005). Profesionalisme Guru dan Peningkatan Mutu Pendidikan di Era Otonomi Daerah. Makalah disampaikan pada Seminar Nasional Pendidikan. Dewan Pendidikan Kabupaten. Wonogiri 23 Juli 2005.

[17] Kanji, H., Nursalam, N., Nawir, M., \& Suardi, S. (2019). Evaluasi Integrasi Pendidikan 
Karakter dalam Pembelajaran Ilmu Pengetahuan Sosial di Sekolah Dasar. JED (Journal of Etika Demokrasi), 4(2).

[18] Kanji, H., Nursalam, N., Nawir, M., \& Suardi, S. (2020). Integration of social care characters and moral integratif on social science lessons in elementary school. Al-ishlah: Jurnal Pendidikan, 12(2), 413-427.

[19] Kanji, H., Nursalam, N., Nawir, M., \& Suardi, S. (2020). Supporting and Inhibiting Factors of Character Education in Learning Social Studies at Primary Schools. JED (Journal of Etika Demokrasi), 5(1), 1-14.

[20] Purbowati, Dani. (2020). Memahami Karakteristik Siswa Sebagai Peserta Didik Saat Belajar Mengajar. https://akupintar.id/info-pintar/-/blogs/ (diakses tanggal 04 November 2020)

[21] Ratnawulan Elis, (2015) Evaluai Pembelajaran, Bandung:CV PUSTAKA SETIA

[22] Rasyid Mulyani, (2012). perencanaan pembelajaran, univeritas muhammadiyah Makassar

[23] Rahmawati, M.I. (2014). Analisis Kesesuaian Kompetensi Guru Dengan Kurikulum 2013.Skripsi. Surakarta: FKIP Universitas Muhammadiyah Surakarta.

[24] Sani Ridwan Abdullah, (2019). Strategi Belajar Mengajar. Depok: Rajagrafindo Persada.

[25] Suciu AL \& L Mata. (2010) Pedagogical competences- the key to efficienteducation.International Online Journal of Educational Science 3 (2) 2010 : 411-423.

[26] Sugiyono, (2012) Metode Penelitian Kualitatif Kuantitatif dan $R \& D$ Bandung: Alfabeta,

[27] Suprihatiningrum Jamil, (2016) Guru Profesional Jogjakarta:AR-RUZZ MEDIA,

[28] Suardi, S., Herdiansyah, H., Ramlan, H., \& Mutiara, I. A. (2019). Implementasi Pendidikan Karakter Melalui Mata Pelajaran Pendidikan Kewarganegaraan di SMA Jaya
Negara Makassar. JED (Journal of Etika Demokrasi), 4(1), 22-29.

[29] Suardi, S. (2018). Penerapan Model Pembelajaran Saintifik Approacd Berbasis Media Pembelajaran Kearifan Lokal pada Mata Kuliah Dasar-Dasar Sosiologi dalam Membangun Karakter dan Meningkatkan Hasil Belajar Mahasiswa Pendidikan Sosiologi Universitas Muhammadiyah Makassar. JED (Journal of Etika Demokrasi), 3(2).

[30] Suardi, S. (2017). Peningkatan Hasil Belajar Sosiologi Pokok Bahasan Interaksi Sosial Melalui Metode Diskusi pada Siswa Kelas X MA. Muhammadiyah Panaikang Kacamatan Bissappu Kabupten Bantaeng. JED (Journal of Etika Demokrasi), 2(1).

[31] Suardi, S., Megawati, M., \& Kanji, H. (2018). Pendidikan Karakter di Sekolah (Studi Penyimpangan Siswa di Mts Muhammadiyah Tallo). JED (Journal of Etika Demokrasi), 3(1), 75-84.

[32] Suardi, S., \& Nursalam, N. (2020). Penerapan Model Pembelajaran Saintifik Approach Berbasis Media Classroom. Indonesian Journal of Sociology, Education, and Development, 2(2), 85-94.

[33] Trianto Ibnu Badar, (2017?) Mendesain Model Pembelajaran Inovatif, Progresif, Dan Kontekstual.cet ke 3:Jakarta : kencana

[34] Uno HB. (2009). Profesi Kependidikan Problema, solusi, dan ReformasiPendidikan di Indonesia. Jakarta: Bumi Aksara

[35] Winarno. (2014). Pembelajaran Pendidikan Kewarganegaraan: Isi, Strategi, dan Penilaian. Jakarta: Bumi Aksara

[36] Peraturan Menteri Pendidikan Nasional. (2007). Peraturan Menteri Pendidikan Nasional nomor 16 tahun 2007 tentang Standar Kualifikasi Akademik dan Kompetensi Guru. Jakarta: BSNP.

[37] Undang-undang Republik Indonesia. 2005. Undang-undang Republik Indonesia nomor 14 tahun 2005 